\title{
"Economic and management approach to defining effective projects for enterprise development under risks and uncertainty"
}

\begin{tabular}{|c|c|}
\hline \multirow{4}{*}{ AUTHORS } & Kateryna Boiarynova iD https://orcid.org/0000-0001-5879-2213 \\
\hline & Kateryna Kopishynska iD https://orcid.org/0000-0002-1609-2902 \\
\hline & Nataliya Hryhorska id https://orcid.org/0000-0001-6139-2296 \\
\hline & R http://www.researcherid.com/rid/F-8925-2019 \\
\hline ARTICLE INFO & $\begin{array}{l}\text { Kateryna Boiarynova, Kateryna Kopishynska and Nataliya Hryhorska (2019). } \\
\text { Economic and management approach to defining effective projects for enterprise } \\
\text { development under risks and uncertainty. Problems and Perspectives in } \\
\text { Management, 17(4), 299-313. doi:10.21511/ppm.17(4).2019.25 }\end{array}$ \\
\hline DOI & http://dx.doi.org/10.21511/ppm.17(4).2019.25 \\
\hline RELEASED ON & Tuesday, 24 December 2019 \\
\hline RECEIVED ON & Wednesday, 23 October 2019 \\
\hline \multirow[t]{2}{*}{ ACCEPTED ON } & Monday, 09 December 2019 \\
\hline & $(\mathrm{sc}) \mathrm{EY}_{\mathrm{EY}}$ \\
\hline LICENSE & $\begin{array}{l}\text { This work is licensed under a Creative Commons Attribution } 4.0 \text { International } \\
\text { License }\end{array}$ \\
\hline JOURNAL & "Problems and Perspectives in Management" \\
\hline ISSN PRINT & $1727-7051$ \\
\hline ISSN ONLINE & $1810-5467$ \\
\hline PUBLISHER & LLC "Consulting Publishing Company "Business Perspectives" \\
\hline FOUNDER & LLC "Consulting Publishing Company "Business Perspectives" \\
\hline
\end{tabular}

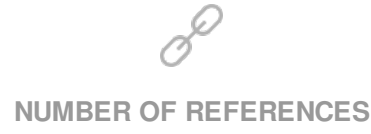

35

\section{NUMBER OF FIGURES}

6

\section{ニニะ}

NUMBER OF TABLES

4

(C) The author(s) 2022. This publication is an open access article. 


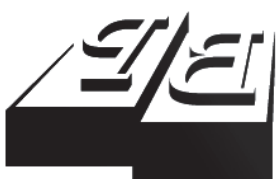

BUSINESS PERSPECTIVES

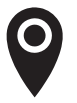

LLC "CPC "Business Perspectives" Hryhorii Skovoroda lane, 10, Sumy, 40022, Ukraine

www.businessperspectives.org

Received on: $23^{\text {rd }}$ of October, 2019 Accepted on: $9^{\text {th }}$ of December, 2019

(c) Kateryna Boiarynova, Kateryna Kopishynska, Nataliya Hryhorska, 2019

Kateryna Boiarynova, Doctor of Economics, Associate Professor, Associate Professor of the Management Department, Faculty of Management and Marketing, National Technical University of Ukraine "Igor Sikorsky Kyiv Polytechnic Institute”, Ukraine.

Kateryna Kopishynska, Ph.D. in Economics, Senior Lecturer of the Management Department, Faculty of Management and Marketing, National Technical University of Ukraine "Igor Sikorsky Kyiv Polytechnic Institute”, Ukraine.

Nataliya Hryhorska, Ph.D. in Economics, Associate Professor of Zinovia Maniva Department of Entrepreneurship, Trade and Stock Exchange, Faculty of Management and Business Analytics, King Danylo University, Ukraine.

\section{(ㄷ)(i)}

This is an Open Access article, distributed under the terms of the Creative Commons Attribution 4.0 International license, which permits unrestricted re-use, distribution, and reproduction in any medium, provided the original work is properly cited.
Kateryna Boiarynova (Ukraine), Kateryna Kopishynska (Ukraine),

Nataliya Hryhorska (Ukraine)

\section{ECONOMIC AND MANAGEMENT APPROACH TO DEFINING EFFECTIVE PROJECTS FOR ENTERPRISE DEVELOPMENT UNDER RISKS AND UNCERTAINTY}

\begin{abstract}
Enterprise development is dependent on the implementation of projects that contribute to improving economic performance. Considering this the need to apply the economic and management approach to the definition of effective projects under risks of reduced enterprise profitability due to the uncertain economic environment is justified. The study used scientific abstraction, formalization, causal relationship, time series analysis, variational range-based standardization, parameter minimization according to maximum and minimum values. The approach is created to evaluate the profitability dynamics of the production, management and finance subsystems of the enterprise, to monitor the deviations in the established corridor of their sufficient levels, to systematically control for the dynamics of the enterprise development to form the effective project portfolio, as well as to manage the risk reduction for projects that are inappropriate for development. The approach approbation, using Ukrainian machinebuilding enterprises as an example, has found enterprises with the level of development dynamics lower than the corridor determined. This indicates the risks of implementing inefficient projects and the need for systematic adjustment of their portfolio. The enterprises whose business operations belong to the fourth technological paradigm should implement projects to increase the profitability of the production and management subsystems, and those from the fifth paradigm should execute projects for the rise in the finance subsystem profitability.
\end{abstract}

\section{Keywords}

project portfolio, development, result-based management, uncertainty, profitability, machinebuilding enterprises, Ukraine

\section{JEL Classification D20, D81, O12}

\section{INTRODUCTION}

The volatile economic environment, the variability of economic growth factors and key success factors create uncertainty in identifying effective projects that would have an impact on improving the performance of Ukrainian enterprises. Uncertainty is characterized by the lack of information in the decision-making process both on the research status object and its external environment (Vitlinsky \& Velikoivanenko, 2004). Uncertainty risk is a consequence of the likely impact of environmental factors on project implementation (Dyachenko, 2018), a likely event contributing to the loss of the ability to achieve the project's outputs or individual parameters (Sultanov, 2019). The combination of these interpretations allows to state that in the context of uncertainty of changes in the external economic environment, the enterprise performance is influenced by external threats and risks. These risks can include changes in the legal framework, the banking system instability in terms of lending, volatile exchange rates, unstable product demand, rapid scientific and technological progress 
and innovation, changes in consumer preferences, shortage of highly qualified personnel, lack of engineering and industrial production staff in nonprofessional occupations. That is, the emergence of risks of implementing inefficient projects depends primarily on the enterprise's uncertain environment.

While ensuring their existence and development, enterprises do not execute projects but their portfolios. This allows for the risk allocation, suspension or activation of projects in the process of continuous operation. Under uncertainty and risk, the long-term forecasting of project success rates in enterprise development is inaccurate and requires more flexible approaches to their establishment. These approaches should not be based on a strategic assessment of projected results, but on an ongoing evaluation of the economic impact of projects for the enterprise and using result-based management on this basis (the process of obtaining concrete, thoughtful, and planned results according to objective opportunities) (Strochilina, 2015). This actualizes the issue of applying the economic and management approach to defining effective projects for enterprise development.

\section{LITERATURE REVIEW}

Scientists pay attention to the issue of determining the enterprise project effectiveness. They also focus on improving project evaluation methods. In particular, Romanova and Vedyaeva (2018) investigate the commercial effectiveness of investment projects based on 1) financial evaluation (on the basis of profitability, turnover, financial sustainability and liquidity ratios); 2) economic evaluation based on static methods (profit margins, payback period, average rate of return on investment, profitability) and dynamic methods (discounting) (Romanova \& Vedyaeva, 2018). Attention is also paid to identifying the impact of project implementation at the enterprise. Thus, Mutovkina and Sergeev (2019), when considering an objective evaluation and selection of a project of technical re-equipment of an industrial enterprise, define many directions for their efficiency: technical, technological, social, making calculations based on methods of fuzzy logic and fuzzy sets. Many studies focus on the management aspect of project execution, in particular Sonta-Draczkowska and Mrozewski (2019) in the perspective of integrating project management, new product development and entrepreneurial perspective, investigate the role of project management and measures of their success. Rostova, Shirokova, and Sokolitsyna (2019) propose an approach for detailed planning in the early stages of a project through quality monitoring, risk assessment, and communication within the project team. Kaczorowska, Słoniec, and Motyka (2018) explore the issue of project portfolio formation, stressing the importance of linkages between individual projects and the organization's strategy in creating its value. They consider profitability, life cycle phase, resources and revenue generated as the important criteria for project selection (Kaczorowska, Słoniec, \& Motyka, 2018). Khlynin, Sorvina, Gryazev, and Sabinina (2018) propose to select projects taking into account the improvement of the enterprise's economic health and ensuring that they achieve the desired strategic development trajectory. There is also a scientific interest in determining the projects effectiveness, taking into account risk and uncertainty. Ostapiuk, Karmaza, Kurylo, and Timchenko (2017) address the issue of economic security and decision-making to attract additional sources of funding while providing a detailed analysis of possible and existing risks of the project. Biyans'ka (2010) explores the issue of assessing the economic effectiveness of innovative projects taking into account the risk of their execution and the determinants of evaluating the characteristics of innovative projects and decision-making problems. Ivanenko, Hrushko, and Frantsuz (2018) analyze the choice of mutually exclusive projects that cannot be completed in parts. Therefore, one project should be selected and all other rejected. Dyachenko (2018) notes that it is important during the project management to pay due attention to identifying the risk essence, possible losses while assessing the expediency of decision-making, developing measures to protect against possible financial losses. Kotsyuba (2018), focusing on the phenomenon of uncertainty, believes that project effectiveness can be interpreted as the ratio of the chances at positive economic results to the risk of failure upon its implementation; with that, cost effective is a project whose chances at success outweigh the risk of failure significantly. 
The research pays sufficient attention to approaches to determining the effectiveness of projects directly. However, the complexity of the issue of the project utility implemented in terms of economic consequences for the enterprise development under uncertainty and taking management measures to minimize their inefficiency risks need further research.

\section{AIMS}

The purpose of the article is to substantiate the economic and management approach to defining effective projects for the enterprise development at the risk of diminishing profitability in uncertain economic environment.

\section{METHODS}

Identification of effective projects for business development requires a flexible approach that includes both assessing economic performance and managing the feasibility of their further implementation. The proposed economic and management approach is based on the functional management of the enterprise project portfolio based on determining the economic consequences of their implementation. Continuity of the enterprise operation implies that in each study period projects can both begin and end, but the consequences of their partial or full implementation affect the economic performance. This leads to an assessment not of static project efficiency but of dynamic one, which, according to Huerta de Soto, includes static efficiency and depends on the capacity level for entrepreneurship and coordination (Huerta de Soto, 2011). In this case, a systematic analysis of the effects that the enterprise receives from the implementation of a set of projects will allow reducing uncertainty and using result-based management in their further selection.

Profitability, or relevant indicators reflecting the return on investment in the projects and the effect obtained by the enterprise, can be considered as an indicator for determining effective projects for enterprise development. In addition, minimizing the risks of project execution is primarily aimed at avoiding losses, and profitability is a key index of profitability that depends on the cost level, including the totality of projects executed. Given that a dynamic approach involves studying objects in development, based on a retrospective analysis of 5-15 past years and forecasting parameters (Krutik \& Gorenburgi, 2000), it is advisable to use indicators of profitability dynamics achieved by the company in the process of functioning to identify effective projects for enterprise development under risk and uncertainty. Thus, the proposed economic and management approach to the definition of effective projects for the enterprise development consists in evaluating the enterprise profitability dynamics, monitoring the deviations in the established corridor of their sufficient level, systematic tracking of the enterprise development to form an effective project portfolio and manage the risk reduction of projects that are inappropriate for development (Figure 1). At the same time, to form an effective project portfolio and promptly respond to the risks of their inefficient implementation, it is desirable to reveal their impact on the development not as a single set but based on the key functional subsystems of the enterprise, namely, production, management and finance. The proposed economic and management approach (Figure 1) includes a number of steps.

1. Specifying indicators of the enterprise profitability dynamics as a result of the current project portfolio execution. To identify effective projects for the company development, it is reasonable not to use static indicators of profitability in the accounting period but the indicators of its dynamics (1). This will identify the risks of diminishing returns due to cost overruns for projects that do not sufficiently generate revenue growth and make management decisions to optimize them.

$$
R_{i}^{D}=\frac{\Delta R_{i}^{T_{n}: T_{n-1}}}{\max _{\mathbf{T}} R_{i}^{T_{n}}-\min _{\mathbf{T}} R_{i}^{T_{n}}},
$$

where $R_{i}^{D}$ - profitability dynamics indicator, $R^{T_{n}}$ - profitability indicator, $T_{n}-$ evaluation period.

Formula (1) is based on the mathematical apparatus (Jerina \& Vastchajev, 1999), the approach was partially used in the study (Gavrysh \& Boiarynova, 2017). 


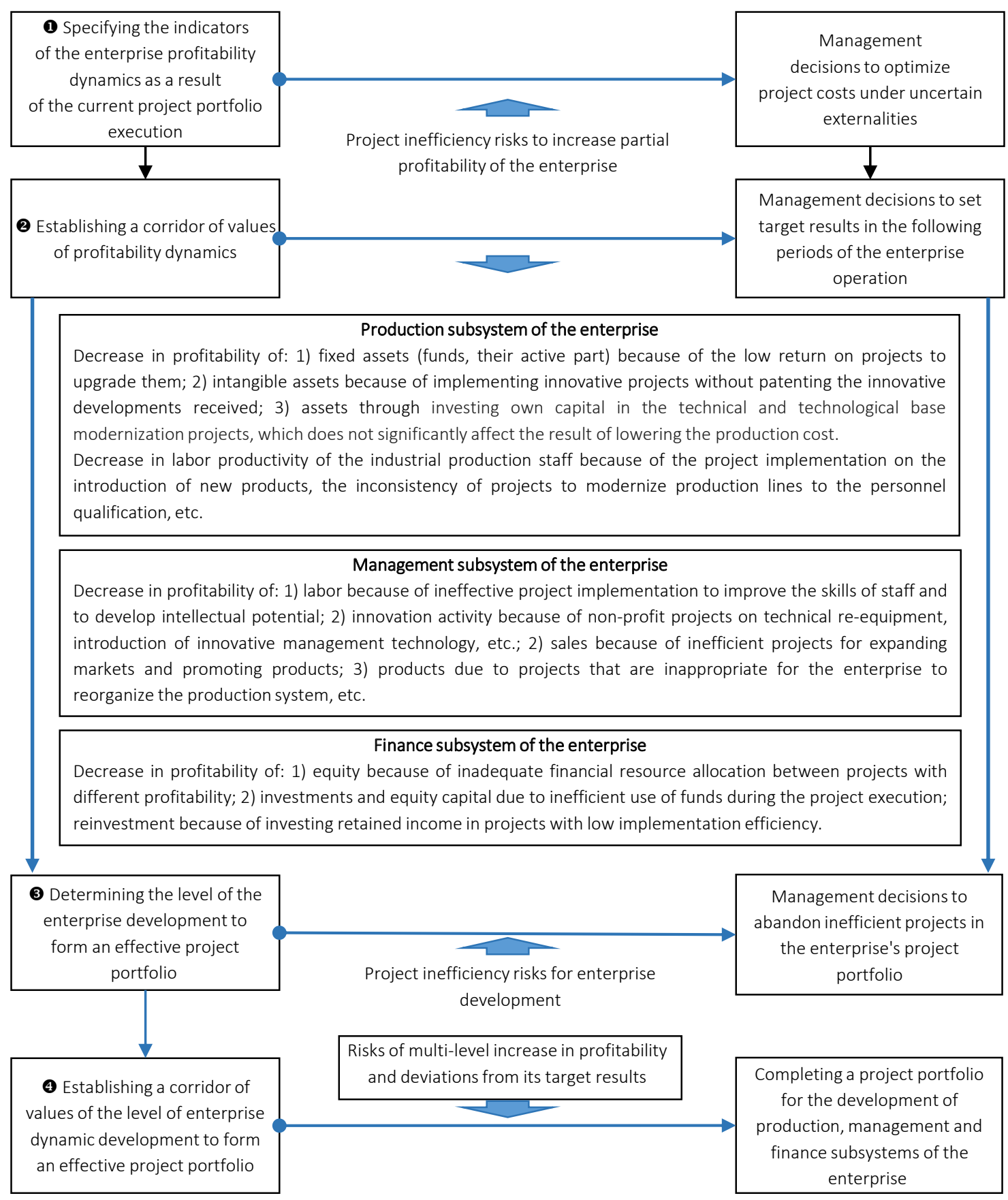

Figure 1. Structural-logical scheme of economic and management approach to defining effective projects for enterprise development under risks and uncertainty

It is advisable to analyze profitability in terms of production, management and financial subsystems to see the rapid change of projects in the enterprise portfolio due to the risks of their inefficiency under uncertain influence of environmental factors.

Profitability of the enterprise production subsystem according to the consequences of the project port- folio execution. Increasing the profitability of the enterprise production subsystem reflects a stable positive effect of projects designed to improve the activities of industrial-production personnel, innovative renewal of fixed assets, increase the effect of using intangible assets in production, efficient functioning of production facilities, increase financial investment in the production development. According to these objectives, effective pro- 
jects should be selected based on the increase in profitability of the active part of fixed assets for production purposes, intangible assets (according to the principle of the asset profitability calculation (Ministry of Finance of Ukraine, State Property Fund of Ukraine, 2001)), profitability of production costs, production profitability, return on assets (calculated according to the State Tax Service of Ukraine, 1998), profitability of production funds (Bankruptcy Agency for Businesses and Organizations, 1997) and labor productivity (Ministry for Development of Economy, 2006). Detecting a decrease in fixed asset profitability (funds, their active part) will allow neutralizing the risks of low return on projects for their renewal; profitability of intangible assets - risks of implementation of innovative projects without patenting of the received innovative developments, due to which the profit was increased through licenses, low return on attraction and use of intangible assets in production activity; return on assets - risks of investing equity in projects to modernize the technological base, which does not significantly affect the reduction in cost of production. The analysis of labor productivity trends of industrial and production personnel will help to prevent risks of executing new product implementation projects, the inconsistency of projects on the production line modernization with personnel skill level, etc.

Profitability of the enterprise management subsystem based on the consequences of the project portfolio implementation. Projects in this area are aimed at improving the efficiency of: a) personnel management, i.e., development of knowledge and intellectual potential; b) innovation management, i.e., innovative processes for creating conditions and appropriate communications; c) business management, i.e., the effective interaction of the enterprise's internal and external business systems. To analyze the personnel management projects, it is advisable to use return on labor (Koval'ov et al., 2010) taking into account the senior management costs. Keeping track of its reduction will reduce the risk of ineffective implementation of staff development projects. The project effectiveness in terms of innovation management can be determined based on:

- the innovative renewal profitability, which is in the economic result from projects aimed at technical re-equipment, acquisition of fixed assets, intangible assets, and innovative technologies used in management (2):

$$
R_{\text {Iup }}=\frac{N P}{C_{\text {t.e. }}+C_{\text {f.a }}+C_{i . a}+C_{i}+C_{\text {t.m.i }}},
$$

where $R_{I u p}$ - innovative renewal profitability, $N P$ - net profit, $C_{t . e}$ - technical re-equipment costs, $C_{f . a}$ - cost of fixed assets acquisition, $C_{i . a}$ - cost of intangible assets acquisition, $C_{i}$ - innovation costs, $C_{t . m . i}$ - purchase costs of innovative technologies used in management;

innovation cost profitability (Kuzmin et al., 2009), reflecting the effect of the margin between the price and the cost of innovative products;

- the return on intellectual capital in the enterprise market value, which will characterize the effectiveness of the management system for intellectualized economic resources (3):

$$
K_{I K}=\frac{M V E}{C_{I K}}
$$

where $K_{I K}$ - the ratio of return on intellectual capital, $M V E$ - enterprise market value, $C_{I K}$ intellectual capital value.

Observing the change in the profitability of innovative activities will reduce the risks of implementing non-profit projects on technical re-equipment, introduction of innovative management technologies, $R \& D$ on the creation of new products.

From the business management perspective, effective projects for the enterprise will increase return on sales (Audit Chamber of Ukraine, 2001), products, and sales based on the financial result from operating activities (Audit Chamber of Ukraine, 2001; Ministry of Finance of Ukraine, 2016). Such an analysis will allow identifying the risks of reducing return on sales because of inefficient projects for expanding markets, product promotion, projects that do not meet the enterprise needs in reorganizing the production system, etc.

Profitability of the enterprise financial subsystem based on the consequences of the project portfo- 
lio implementation. Return on equity (Audit Chamber of Ukraine, 2001; Ministry of Finance of Ukraine, 2016), sales based on the financial result from ordinary activities (Ministry for Development of Economy, Trade and Agriculture of Ukraine, 2010), investment (Holovchenko, Zems'ka, 2009), equity, reinvestment (Finalon. com, 2019), and the increase in the enterprise market value are the indicators for evaluating the profitability of the enterprise financial subsystem (4):

$$
K_{M V E}=\frac{M V E_{r . p}}{0.5\left(M V E_{r . p}+M V E_{p . p}\right)},
$$

where $K_{M V E}$ - market value growth factor, $M V E_{r . p}$ and $M V E_{p . p}$ - market value of the enterprise for the reporting and previous periods, respectively.

When identifying effective projects for the enterprise financial subsystem, profitability diagnostics will prevent the risks of its equity reduction because of inappropriate allocation of financial resources between projects with different profitability. The decrease in return on investment and equity will indicate the risks of reducing the shareholders' and investors' interest in financing the enterprise because of inefficient fund utilization during the project implementation. Reducing the reinvestment rate will reveal the risk of investing retained earnings in low-yield projects. The identification of projects, investments in which do not increase the enterprise market value, will make it possible to identify the risks of reducing the financial and economic security of the enterprise.

2. Setting a corridor of target values for the enterprise profitability dynamics to form an effective project portfolio. To form an effective portfolio development project, it is necessary to establish a corridor of profitability targets and to monitor the level of fluctuation of the effects obtained. When determining the profitability dynamics enterprise in the appropriate field, it is possible to establish a value corridor of its desired results (5). The result getting in such a corridor is considered sufficient achieved effect from the projects in the current period of the enterprise operation.

$$
\begin{aligned}
R_{l}^{\operatorname{margin}} & =\max _{\mathbf{T}}\left(\frac{\sum_{\mathbf{E}} \varpi_{R_{i}^{D}, E_{m}}^{T_{n}}}{E}\right), \\
R_{h}^{\text {margin }} & =\frac{\sum_{\mathbf{T}} \max _{\mathbf{E}}\left(\begin{array}{c}
\varpi_{R_{i}^{D}, E_{m}}^{T_{n}} \\
R^{\prime}
\end{array}\right)}{E},
\end{aligned}
$$

where $R_{l}^{\text {margin }}, R_{h}^{\text {margin }}$ - the margins of the corridor values of the profitability dynamics $\varpi_{R^{D}, E}^{T_{n}}$ - smooth (two-year period) value of the profitability dynamics of the studied enterprise $\left(E_{m}\right), E$ - the number of enterprises in the appropriate economic activity.

Formula (5) is based on a mathematical apparatus (Beliakov et al., 2007); the method was partially used in the study (Gavrysh \& Boiarynova, 2017).

At this stage, management decisions will relate to the determination of the target results that should be achieved in the subsequent periods of the enterprise operation.

3. Determination of the level of the enterprise development to form an effective project portfolio. This dynamic is proposed to define as the aggregate result of the achieved profitability calculated based on the level of achieving the desired results by the actual indicators, taking into account the complex growth of indicators for the production, management and financial subsystems of the enterprise (6). This will identify and anticipate the risks of multi-level profitability growth with significant deviations from target results. Management decisions according to this indicator should be aimed at abandoning inefficient projects in the enterprise project portfolio.

$$
\begin{aligned}
& D D=\frac{\sum\left(R_{i}^{\text {margin }} \cdot R_{i}^{D}\right)}{\sqrt{\sum\left(R_{i}^{\text {margin }}\right)^{2}} \sqrt{\sum\left(R_{i}^{D}\right)^{2}}} \times \\
& \times \sum \exp \left(-\sqrt{\sum_{R_{t} \in \mathrm{R}}\left(R_{i}^{D}-R_{i}^{\text {margin }}\right)^{2}}\right),
\end{aligned}
$$

where $D D$ - the level of the enterprise dynamic development to form an effective project portfolio, $R^{\text {margin }}$ - the margin of the profitability dynamics value corridor, $R_{i}^{D}$ - profitability dynamics indicator. 
Formula (6) is based on a mathematical apparatus (Dehtyarev \& Dehtyareva, 2012; Korn and Korn, 1974).

4. Setting a value corridor of the enterprise dynamic development to form an effective project portfolio (7):

$$
\begin{aligned}
D D_{l}^{\text {margin }} & =\max _{\mathbf{T}}\left(\frac{\sum_{\mathbf{E}} \varpi_{D D, E_{m}}^{T_{n}}}{E}\right), \\
D D_{h}^{\text {margin }} & =\frac{\sum_{\mathbf{T}} \max _{\mathbf{E}}\left(\varpi_{D D, E_{m}}^{T_{n}}\right)}{E},
\end{aligned}
$$

where $D D_{l}^{\text {margin }}, D D_{h}^{\text {margin }}$ - margins of the value corridor of the enterprise dynamic development, $\varpi_{D D, E_{m}}^{T_{n}}$ - smooth (two-year period) value of the dynamic development of the enterprise under study $\left(E_{m}\right), E$ - the number of enterprises in the appropriate field of economic activity.

Formula (7) is based on a mathematical apparatus (Beliakov et al., 2007).

The defined corridor of the enterprise development level will allow tracking the tendencies of its change under uncertainty (above, below or according to the range) to form an effective project portfolio for production, management and financial subsystems of the enterprise, using the current result adjustment (Figure 2).

\section{RESULTS}

The proposed economic and management approach is tested using machine-building enterprises, which are leaders in the industrial sector of Ukraine. The study takes into account the fact that their activity belongs to both the fourth and the fifth technological paradigms (see Appendix A). According to the approach proposed (see Figure 1) and given the enterprises' open-access information (Ukrainian Stock Market Infrastructure Development Agency, 2018), the value corridor for development of enterprises' production subsystems is found to be similar for both groups (Table 1). The obtained results for the value corridor of the profitability dynamics indicators made it possible to state that for the machine-building enterprise, whose economic activity belongs to the fourth technological paradigm, the projects on the development of the enterprise production system provided growth of labor productivity, profitability of production assets and fixed assets. For the fifth paradigm, they ensured growth in profitability of production costs, production, and intangible assets.

According to the enterprise classification into those that exceed, underachieve or comply with the established corridor of dynamics of the enterprise production system development, 40 to $60 \%$ of the enterprises under investigation fell into the area of Below the range. In 2016-2017, their number in the compliance area (According to the

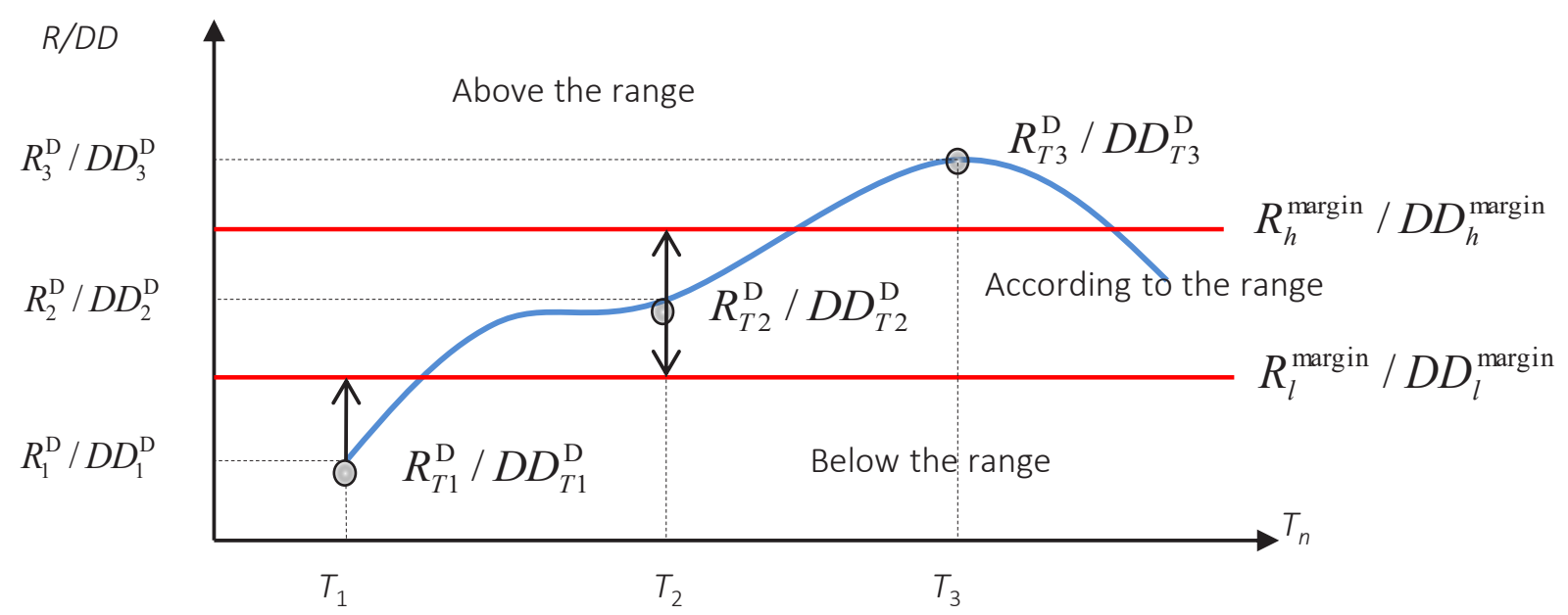

Figure 2. Graphical interpretation of the monitoring of the enterprise development dynamics to diversify projects in the enterprise portfolio 
Table 1. Target values of the enterprise production subsystem development to form an effective project portfolio

\begin{tabular}{|c|c|c|c|c|c|c|c|}
\hline Constituent & \multicolumn{7}{|c|}{ Indicator/value corridor } \\
\hline $\begin{array}{l}\text { Industrial and } \\
\text { production staff }\end{array}$ & \multicolumn{4}{|c|}{ Indicator of the labor productivity dynamics } & \multicolumn{3}{|c|}{$\begin{array}{l}\text { IV TP: } 0.159-0.366 \\
\text { V TP: } 0.093-0.355\end{array}$} \\
\hline Innovations & \multicolumn{2}{|c|}{$\begin{array}{l}\text { Profitability dynamics of } \\
\text { the active fixed assets for } \\
\text { industrial purposes }\end{array}$} & \multicolumn{2}{|c|}{$\begin{array}{l}\text { IV TP: } 0.0363-0.278 \\
\text { V TP: } 0.0234-0.359\end{array}$} & $\begin{array}{c}\text { Profitability } \\
\text { dynamics of } \\
\text { intangible assets }\end{array}$ & \multicolumn{2}{|c|}{$\begin{array}{l}\text { IV TP: } 0.073-0.270 \\
\text { V TP: } 0.056-0.286\end{array}$} \\
\hline Production facilities & \multicolumn{4}{|c|}{ Profitability dynamics of production funds } & \multicolumn{3}{|c|}{$\begin{array}{l}\text { IV TP: } 0.065-0.316 \\
\text { V TP: } 0.029-0.340\end{array}$} \\
\hline Production funding & $\begin{array}{c}\text { Profitability } \\
\text { dynamics of } \\
\text { production costs }\end{array}$ & $\begin{array}{r}\text { IV TP: } \\
0.3 \\
\text { V TP: } \\
0.2\end{array}$ & & $\begin{array}{l}\text { Production } \\
\text { profitability } \\
\text { dynamics }\end{array}$ & $\begin{array}{c}\text { IV TP: } \\
0.083- \\
0.361 \\
\text { V TP: } \\
0.129- \\
0.233\end{array}$ & $\begin{array}{l}\text { Dynamics } \\
\text { of return on } \\
\text { assets }\end{array}$ & $\begin{array}{c}\text { IV TP: } \\
0.089- \\
0.293 \\
\text { V TP: } \\
0.052- \\
0.369\end{array}$ \\
\hline \multicolumn{5}{|c|}{ Dynamic development of the enterprise production subsystem } & \multicolumn{3}{|c|}{$\begin{array}{l}\text { IV TP: 0.52-0.69 } \\
\text { V TP: } 0.56-0.68\end{array}$} \\
\hline
\end{tabular}

Note: IV TP and V TP are for enterprises whose business operations belong to the fourth and fifth technological paradigms, respectively. Static indicators are calculated according to methods proposed by the Ministry for Development of Economy (2006), Ministry of Finance of Ukraine, State Property Fund of Ukraine (2001), State Tax Service of Ukraine (1998), Bankruptcy Agency for Businesses and Organizations (1997). The performance corridor is calculated using formulas (5)-(7).

range) increased, indicating interest in projects for the innovatization, creation and improvement of products, updating the main means to involve intangible assets in these processes (Figure 3).
The analysis of the defined corridor for the development dynamics of the enterprise management subsystem (Table 2) shows their higher range at the enterprises operating within the fifth technological para-

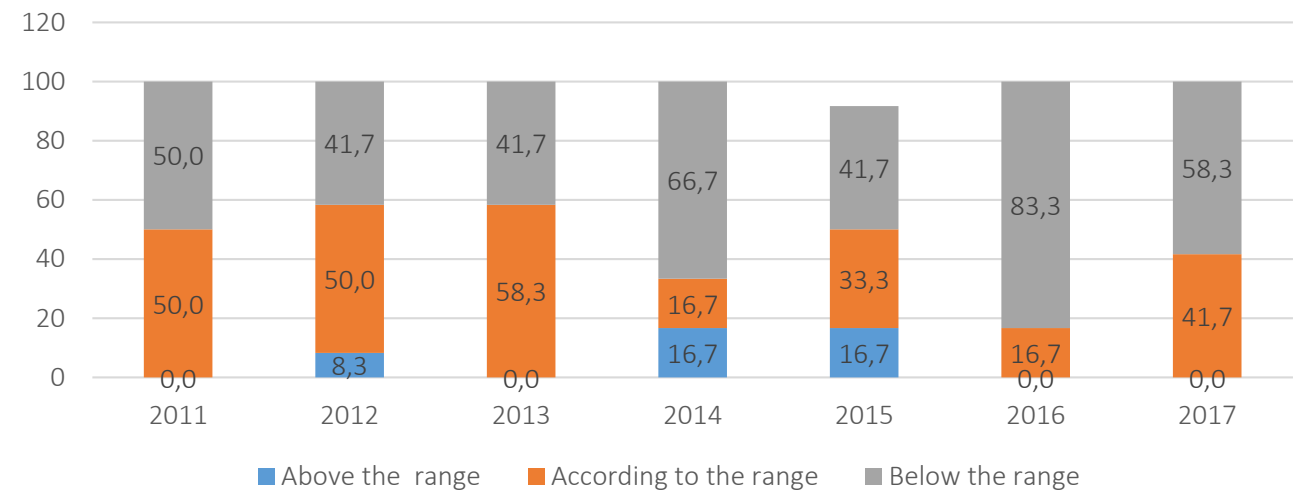

a - the fourth technological paradigm

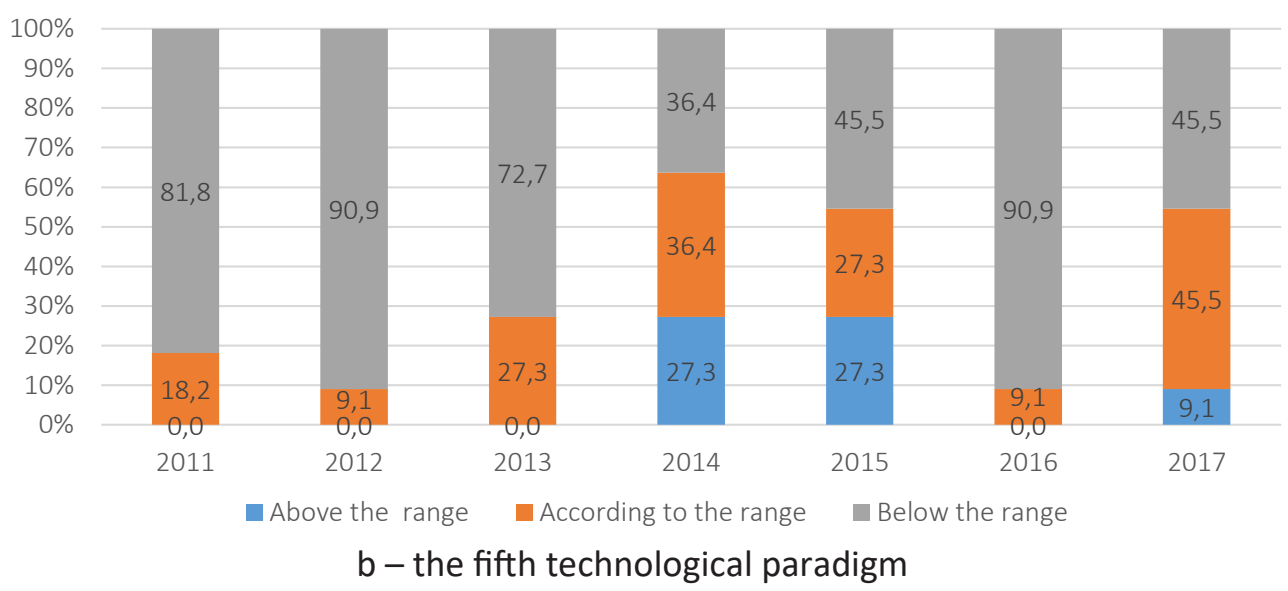

Figure 3. Distribution of machine-building enterprises according to the level of the production subsystem dynamic development in terms of project implementation consequences, \% 
Table 2. Target values of the development of the enterprise management subsystem to form an effective project portfolio

\begin{tabular}{|c|c|c|c|c|c|c|}
\hline Constituent & \multicolumn{6}{|c|}{ Indicator/value corridor } \\
\hline $\begin{array}{l}\text { Personnel } \\
\text { management }\end{array}$ & \multicolumn{3}{|c|}{ Indicator of return on labor profitability } & \multicolumn{3}{|c|}{$\begin{array}{l}\text { IV TP: } 0.041-0.297 \\
\text { V TP: } 0.048-0.348\end{array}$} \\
\hline $\begin{array}{l}\text { Innovation } \\
\text { management }\end{array}$ & $\begin{array}{c}\text { Innovation renewal } \\
\text { profitability }\end{array}$ & $\begin{array}{c}\text { IV TP: } \\
0.029-0.240 \\
\text { V TP: } \\
0.068-0.307\end{array}$ & $\begin{array}{c}\text { Profitability } \\
\text { dynamics of } \\
\text { innovation costs }\end{array}$ & $\begin{array}{c}\text { IV TP: } \\
0.064-0.227 \\
\text { V TP: } \\
0.085-0.306\end{array}$ & $\begin{array}{c}\text { Dynamics of return } \\
\text { on intellectual } \\
\text { capital }\end{array}$ & $\begin{array}{c}\text { IV TP: } \\
0.009-0.175 \\
\text { VTP: } \\
0.072-0.215\end{array}$ \\
\hline $\begin{array}{l}\text { Business } \\
\text { management }\end{array}$ & $\begin{array}{l}\text { Dynamics of } \\
\text { profitability of sales } \\
\text { based on the financial } \\
\text { result from operating } \\
\text { activities }\end{array}$ & $\begin{array}{c}\text { IV TP: } \\
0.033-0.321 \\
\text { V TP: } \\
0.063-0.306\end{array}$ & $\begin{array}{l}\text { Product } \\
\text { profitability } \\
\text { dynamics }\end{array}$ & $\begin{array}{c}\text { IV TP: } \\
0.083-0.361 \\
\text { V TP: } \\
0.128-0.233\end{array}$ & $\begin{array}{c}\text { Dynamics of return } \\
\text { on sales }\end{array}$ & $\begin{array}{c}\text { IV TP: } \\
0.072-0.352 \\
\text { VTP: } \\
0.124-0.256\end{array}$ \\
\hline \multicolumn{4}{|c|}{ Dynamic development of the enterprise management subsystem } & \multicolumn{3}{|c|}{$\begin{array}{l}\text { IV TP: } 0.39-0.61 \\
\text { V TP: } 0.43-0.65\end{array}$} \\
\hline
\end{tabular}

Note: IV TP and V TP are for enterprises whose business operations belong to the fourth and fifth technological paradigms, respectively. Static indicators are calculated according to methods proposed by Koval'ov et al. (2010), Kuz'min et al. (2009), Audit Chamber of Ukraine (2001), Ministry of Finance of Ukraine (2016). The performance corridor is calculated using formulas (5)-(7).

digm (0.43-0.65) due to the increase in the Innovation Management component profitability (Table 2).

In general, $33-36 \%$ of machine-building enterprises (Figure 4) arrear in the According to the range area, that is they correspond to the dynamic development of the enterprise management subsystem. This shows the lack of projects aimed at the promotion and sale of products, the activation of innovation through increased funding for innova-
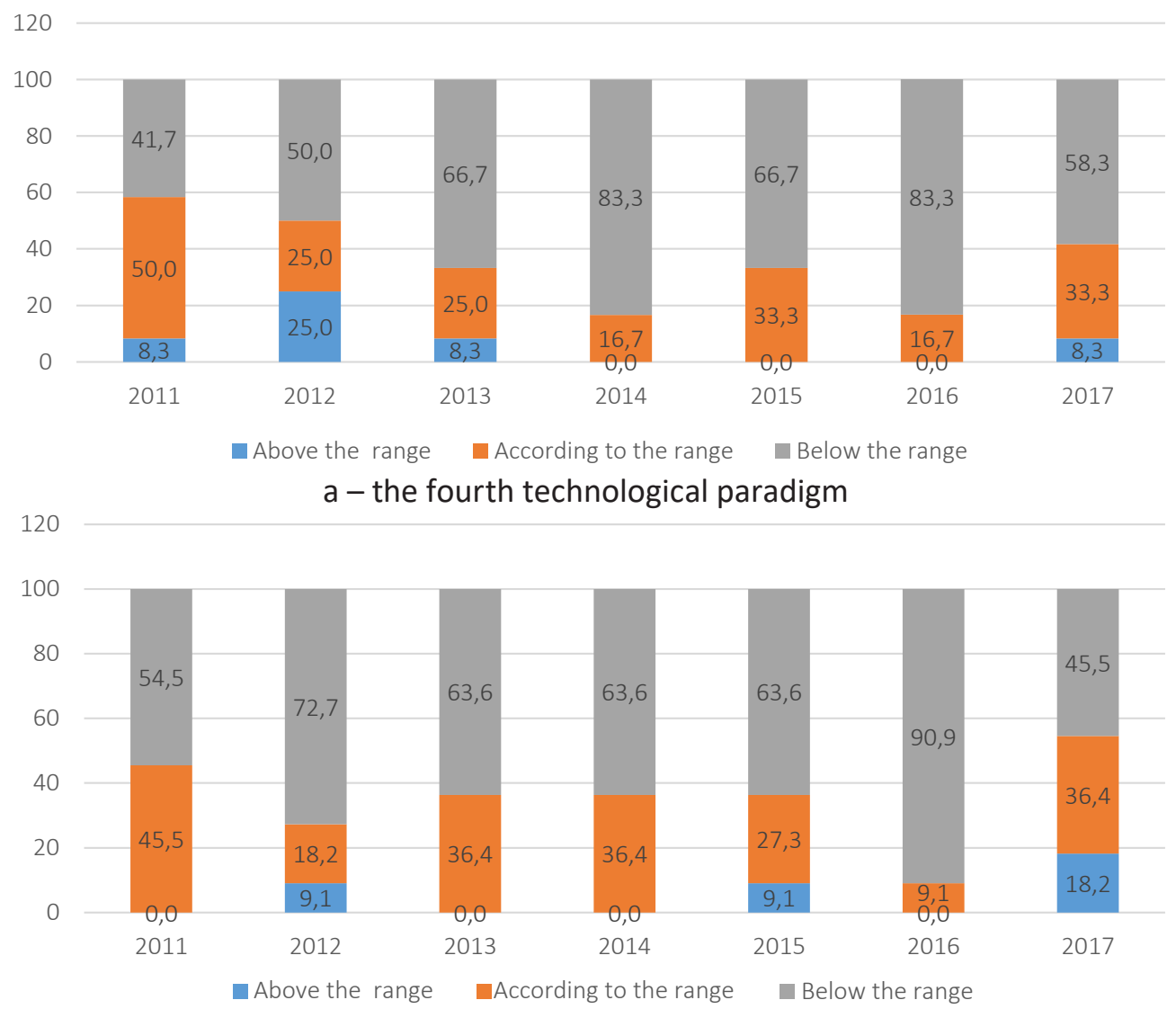

$b$ - the fifth technological paradigm

Figure 4. Distribution of machine-building enterprises by the level of management system dynamic development in terms of project implementation effects, \% 
Table 3. Target values of development of the enterprise financial subsystem to form an effective project portfolio

\begin{tabular}{|c|c|c|c|c|}
\hline Constituent & \multicolumn{4}{|c|}{ Indicator/value corridor } \\
\hline Financial provision & \multicolumn{2}{|c|}{ Return on equity dynamics } & \multicolumn{2}{|c|}{$\begin{array}{l}\text { IV TP: } 0.088-0.292 \\
\text { V TP: } 0.066-0.381\end{array}$} \\
\hline $\begin{array}{l}\text { Financial } \\
\text { and business } \\
\text { effectiveness }\end{array}$ & \multicolumn{2}{|c|}{$\begin{array}{l}\text { Dynamics of return on sales based on the financial } \\
\text { result from ordinary activities }\end{array}$} & \multicolumn{2}{|c|}{$\begin{array}{l}\text { IV TP: } 0.045-0.273 \\
\text { V TP: } 0.081-0.363\end{array}$} \\
\hline Investment & $\begin{array}{l}\text { Return on investment } \\
\text { dynamics }\end{array}$ & $\begin{array}{l}\text { IV TP: } 0.058-0.319 \\
\text { V TP: } 0.025-0.379\end{array}$ & $\begin{array}{l}\text { Return on equity } \\
\text { dynamics }\end{array}$ & $\begin{array}{l}\text { IV TP: } 0.096-0.341 \\
\text { V TP: } 0.071-0.241\end{array}$ \\
\hline $\begin{array}{l}\text { Financial and } \\
\text { economic security }\end{array}$ & $\begin{array}{l}\text { Reinvestment profitability } \\
\text { dynamics }\end{array}$ & $\begin{array}{l}\text { IV TP: } 0.061-0.364 \\
\text { V TP: } 0.107-0.307\end{array}$ & $\begin{array}{l}\text { Dynamics of } \\
\text { profitability and } \\
\text { market value growth }\end{array}$ & $\begin{array}{l}\text { IV TP: } 358, \cdot \cdot \cdot, \cdot 0 \\
\text { V TP: } 0.066-0.362\end{array}$ \\
\hline \multicolumn{3}{|c|}{ Dynamic development of the enterprise financial subsystem } & \multicolumn{2}{|c|}{$\begin{array}{l}\text { IV TP: } 0.38-0.50 \\
\text { V TP: } 0.34-0.55\end{array}$} \\
\hline
\end{tabular}

Note: IV TP and V TP are for enterprises whose business operations belong to the fourth and fifth technological paradigms, respectively. Static indicators are calculated using methods proposed by the Audit Chamber of Ukraine (2001), Ministry of Finance of Ukraine (2016), Ministry for Development of Economy, Trade and Agriculture of Ukraine (2010), Holovchenko and Zems'ka (2009), Finalon.com (2019). The performance corridor is calculated using formulas (5)-(7).

tion, technology, creation of machines, equipment, and management technologies (Kreidych, Bielova, and intellectual capital. However, the modern \& Olijnyk, 2019). This situation can be considered type of sectoral economic development relates to as an effect of risk of management decision inconthe intensified increase in innovation and infor- sistency to the market situation and the lack of inmation potential, the practical use of intellectual novative direction in management actions.

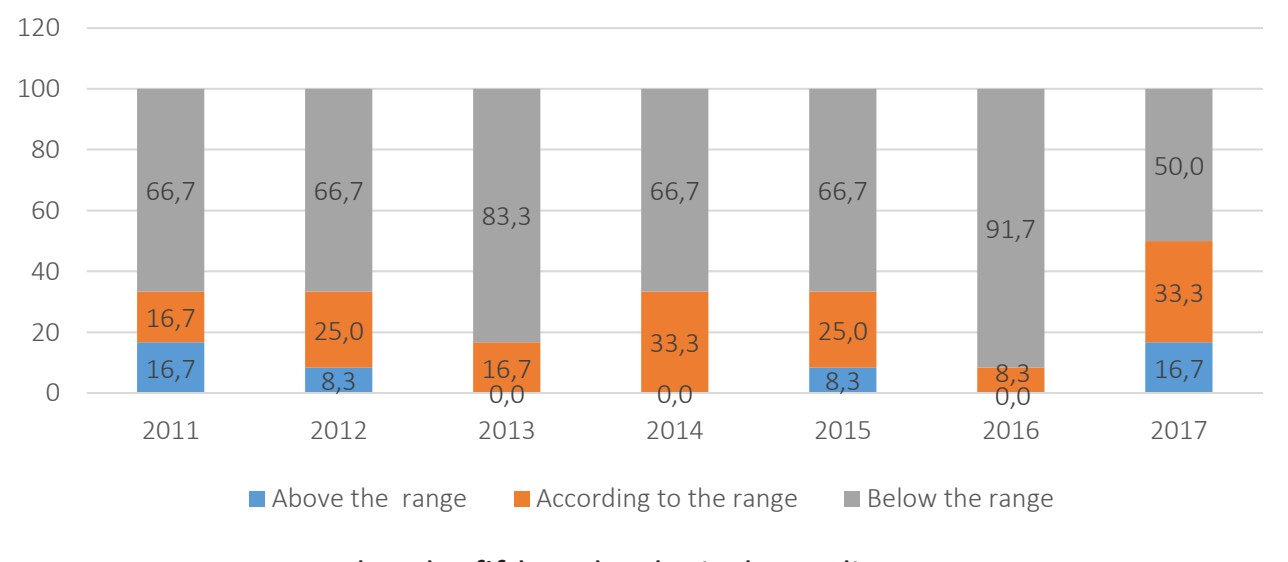

\section{$b$ - the fifth technological paradigm}

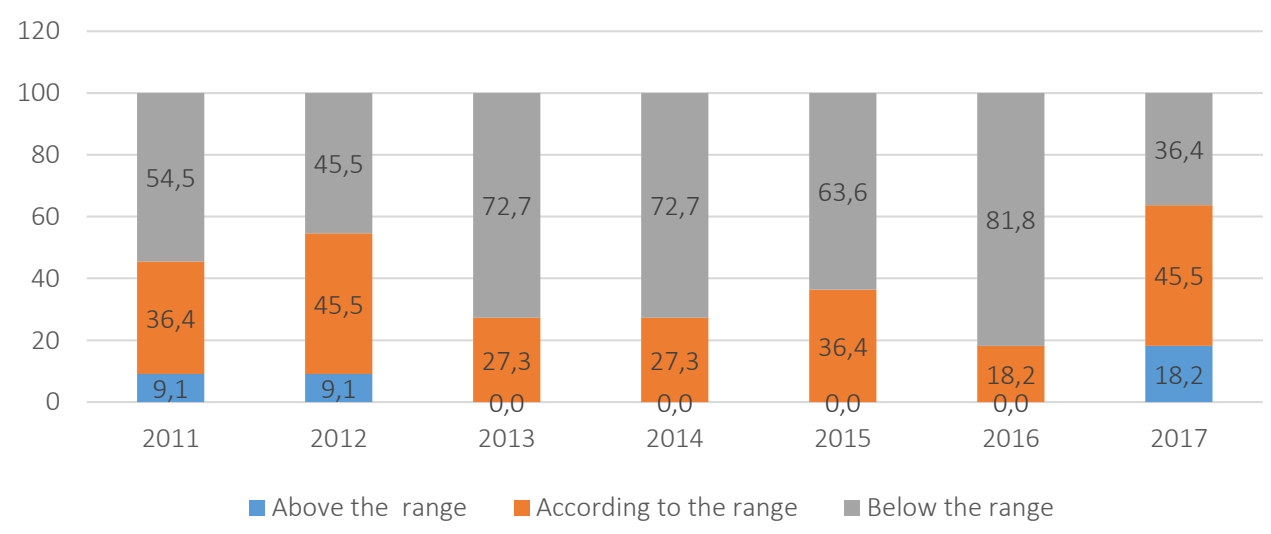

a - the fourth technological paradigm

Figure 5. Distribution of machine-building enterprises by the level of financial system dynamic development in terms of project implementation effects, \% 


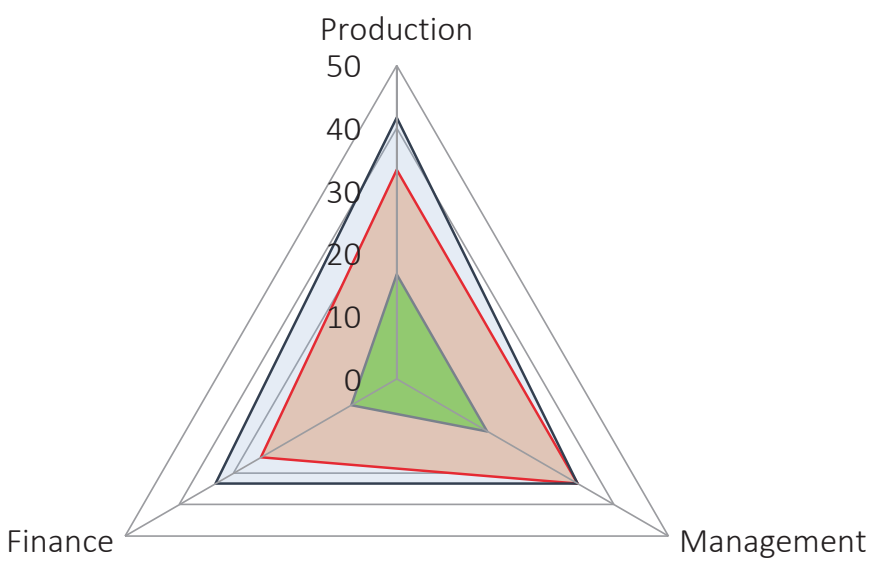

$\square 2015 \square 2016 \quad \square 2017$

a - the fourth technological paradigm

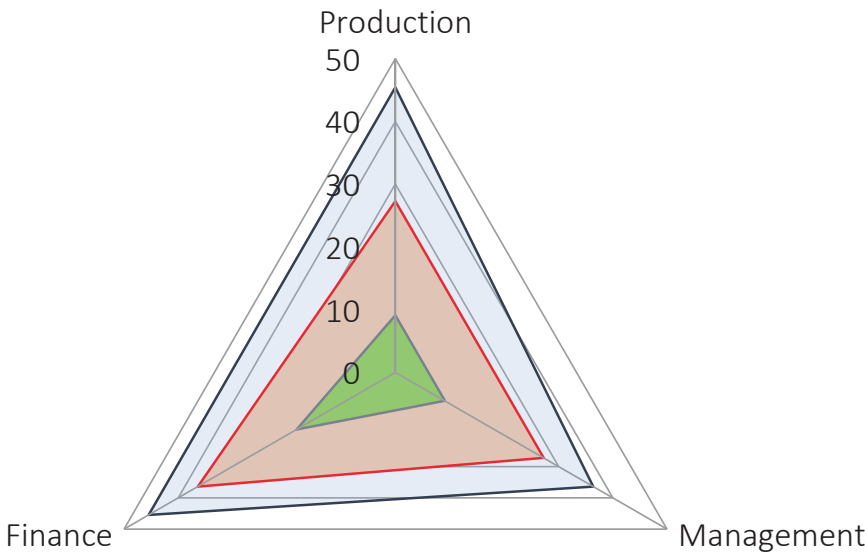

$\square 2015 \quad \square 2016 \quad \square 2017$

$b$ - the fifth technological paradigm

Figure 6. Distribution of machine-building enterprises according to the effectiveness of the projects executed in ensuring the development dynamics, \%

According to the defined corridor of the levels of the enterprise financial subsystem development the management decisions of the machine-building enterprises should focus on projects aimed at increasing return on equity, investment and share capital, as well as maximizing the market value. Compared to the enterprises whose business operation belongs to the fourth technological paradigm, indicators of reinvestment in the enterprise development for the fifth technological paradigm have the higher value corridor (Table 3 ).

The results of the study make it possible to confirm the higher efficiency of the implemented projects for the development of the financial system of machine-building enterprises within the fifth technological paradigm. Starting in 2015, 36.4\%, $18.2 \%$, and $45.5 \%$ of enterprises were in the area 
of correspondence (According to the range) to the development dynamics. However, their significant percentage, as well as the percentage of enterprises whose economic activity belongs to the fourth technological paradigm, had lower rates (Figure 5). This indicates that the projects executed did not fully ensure profitability through cooperation with business partners, use of invested capital of partners and investors, reinvestment and increase in market value.

Having summarized the study results on the development dynamics of Ukrainian ma- chine-building enterprises during 2015-2017 allows for arguing that under risks and uncertainty, it is advisable for the enterprises of the fourth technological paradigm to execute projects aimed at increasing the profitability of the production and management system, namely projects for the development of personnel, innovations, production facilities, production funding, and business management. Whereas for the companies in the fifth technological paradigm, the projects are aimed at improving the profitability of their financial system to receive investment and increase the market value (Figure 6).

\section{CONCLUSION}

The proposed economic and management approach to the definition of effective projects allows to reduce the risk of their inefficiency in order to increase the profitability of the production, management and financial subsystems of the enterprise. Considering the accuracy of multidirectional project execution at the enterprises, it is proposed to determine the level of dynamics of the enterprise development as economic consequences of their implementation and to use on that basis the result-based management to form the future portfolio. In the context of the uncertain externalities, this allows responding promptly to the risks of implementing inefficient projects that reduce the enterprise profitability. The practical approval of the approach used by Ukrainian machine-building enterprises make it possible to reveal enterprises with the level of development below the established corridor and the imbalance between the increase of profitability of production, management and financial subsystems; this indicates risks of implementation of inefficient projects and the need to systematically adjust their portfolios. For enterprises whose economic activity belongs to the fourth technological paradigm, it is advisable to execute projects to develop the production subsystem; for the fifth paradigm enterprises, the projects to develop financial subsystems are recommended. Further research should be aimed at forming a methodological toolkit for project selection based on the enterprise economic growth.

\section{REFERENCES}

1. Audit Chamber of Ukraine. (2001). Metodychni rekomendatsii shchodo pidhotovky audytorskoho vysnovku pry perevirtsi vidkrytykh aktsionernykh tovarystv ta pidpryiemstv-emitentiv oblihatsii (krim komertsiinykh bankiv) [Methodological recommendations for the preparation of the audit report when checking open joint stock companies and bond issuers (except for commercial banks)]. Retrieved from http://ua-info.biz/ legal/baseqp/ua-zmwcnt.htm (In Ukrainian).

2. Bankruptcy Agency for Businesses and Organizations. (1997). Metodyka provedennia pohlyblenoho analizu finansovo-hospodarskoho stanu pidpryiemstv ta orhanizatsii № 81, 27.06.97-3. Rekomendatsii Ahentstva z pytan zapobihannia bankrutstvu pidpryiemstv ta orhanizatsii [Methods of conducting in-depth analysis of financial and economic status of enterprises and organizations No. 81, 06/27/97-3. Recommendations of Bankruptcy Agency for Businesses and Organizations]. Retrieved from http:// zakon4.rada.gov.ua/laws/show/ z0288-97 (In Ukrainian).

3. Beliakov, G., Pradera, A., \& Calvo, T. (2007). Aggregation functions: a guide for practitioners. SpringerVerlag Berlin Heidelberg.

4. Biyanska, I. (2010) Assessment of economic efficiency of investment projects. Visnyk natsionalnoho universytetu "Lvivska politekhnika". Problemy ekonomiky ta upravlinnya, 683, 149-154. (In Ukrainian).

5. Classification of economic activities. (2011-2019). Retrieved from http://www.kved.com.ua/ (In Ukrainian).

6. Dehtyarev, A. M., \& Dehtyareva, E. V. (2012). Geometricheskaya osnova korrelyatsionnogo analiza [The geometric basis of correlation analysis]. Globalnaya yadernaya bezopasnost, 2-3, 42-50. (In Russian).

7. Dyachenko, Y. (2018). Improvement of risk management 
system for investment projects. Naukovi pratsi NDFI, 4(85), 17-29. (In Ukrainian).

8. Finalon.com. (2019). Finansovyy anaaliz predpriyatiya: raschety $i$ vyvody online [Financial analysis of the enterprise: calculations and conclusions online]. Retrieved from https://www.finalon.com (In Russian).

9. Gavrysh, O., \& Boiarynova, K. (2017). The methodological approach to monitoring of the economic and functional state of innovation-oriented machinery engineering enterprises at the modern technological modes. Economic Annals-XXI, 164 (3-4), 65-70. Retrieved from https:// www.ceeol.com/search/articledetail?id=546682

10. Holovchenko, T. M., \& Zemska, H. O. (2009). Profitability as an integral part of financial sustainability of enterprises. VISNYK KHNTU, 3(36), 147-154. (In Ukrainian).

11. Ivanenko, T., Hrushko, V., \& Frantsuz, A. (2018). Optimal investment decision making on the model of production enterprise with limited resources. Investment Management and Financial Innovations, 15(4), 61-68. http://dx.doi. org/10.21511/imfi.15(4).2018.05

12. Jerina, A., \& Vastchajev S. (1999). Generalized multiple indices in socioeconomic researches. $\mathrm{Nau}$ kovi zapysy Kyyevo-Mohylyanskoyi akademii. Ekonomika, 6, 38-41. (In Ukrainian).

13. Jesús Huerta de Soto. (2011). Sotsialno-ekonomicheskaya teoriya dynamichnoy effektyvnosti [Socio-economic theory of dynamic efficiency]. V. Koshkin (trans. from English), A. Kuryaeva (ed.). Chelyabinsk: Sotsium. (In Russian).

14. Kaczorowska, A., Słoniec, J., \& Motyka, S. (2018) Portfolio approach to project management in creation of the organization's value. MATEC Web Conf. III International Conference of Computational Methods in Engineering Science (CMES'18), 252. https://doi.org/10.1051/matecconf/201925206011
15. Khlynin, E. V., Sorvina, O. V., Gryazev, M. V., \& Sabinina, A. L. (2018). Development of theoretical methodological bases for complex estimation of industrial investment projects economic efficiency. Espacios, 39(19). Retrieved from https://www.revistaespacios. com/a18v39n19/a18v39n19p25. pdf

16. Korn, T. M., \& Korn, G. A. (1974). Spravochnik po matematike dlia nauchnykh rabotnikov i inzhenerov [Math reference book for scientists and engineers]. Moscow: Naka. (In Russian).

17. Kotsyuba, O. S. (2018). Methodological analysis of the phenomenon of uncertainty in evaluating of investment project economic efficiency. Ekonomika ta pidpryyemnytstvo: $z b$. nauk. pr., 40, 147-165. (In Ukrainian).

18. Kovaliov, V. M., Lysenko, S. M., Bulavina, I. A., \& Atayeva, O. A. (2010). Metodolohichni pidkhody do vyznachennia efektyvnosti vykorystannia lyudskoho kapitalu [Methodological approaches to determining the efficiency of human capital use]. Formuvannia rynkovoi ekonomiky: $z b$. nauk. prats 2010. Spets. vyp., Sotsialnotrudovi vidnosyny: teoriia ta praktyka, 3, 148-160. (In Ukrainian).

19. Kreidych, I., Bielova, A., \& Olijnyk, G. (2019). Forming the conditions of innovative development of enterprises in the transformation economy. Baltic Journal of Economic Studies, 5(4), 122-129. https://doi.org/10.30525/22560742/2019-5-4-122-129

20. Krutik, A. B., \& Gorenburgi, Yu. M. (2000). Ekonomika nedvizhimosti [Real Estate Economics]. SPb.: Lan. (In Russian).

21. Kuzmin, O. Ye., Didyk, A. M., Kohut, U. I., \& Melnyk, O. H. (2009). Problemy ta teoretykometodychni zasady upravlinnia vytratamy na mashynobudivnykh pidpryiemstvakh [Problems and theoretical and methodological principles of cost management at machine-building enterprises]. Lviv: Triada-plius. (In Ukrainian).

22. Ministry for Development of Economy, Trade and Agriculture of Ukraine. (2006). Metodychni rekomendatsii shchodo stvorennia oznak neplatospromozhnosti pidpryiemstva ta oznachennia diisnosti iz zaluchenniam bankrutstva, aktyvnoho bankrutstva chy dovedennia do bankrutstva: Nakaz Ministerstva ekonomiky Ukrainy № 14, 19.01.2006 [Methodical recommendations on the sign of lack of business opportunity and determining bankruptcy, fictitious bankruptcy, and causing to become bankrupt: The order of the Ministry of Economy of Ukraine No. 14 dated January 19, 2006.]. Retrieved from http://www.me.gov. ua/Documents/Detail?lang=ukUA\&id $=111503 \mathrm{bd}-$ ca7f-4dee-b07cc66c2aa28e03\&title=Metodichni (In Ukrainian).

23. Ministry for Development of Economy, Trade and Agriculture of Ukraine. (2010). Pro vnesennia zmin do Metodychnykh rekomendatsii shchodo vyiavlennia oznak neplatospromozhnosti pidpryiemstva ta oznak dii z prykhovuvannia bankrutstva, fiktyvnoho bankrutstva chy dovedennia do bankrutstva: Nakaz Ministerstva ekonomiky Ukrainy № 1361, 26.10.2010 [On Amendments to the Methodological Recommendations for Identification of Signs of Insolvency of the Company and Signs of Actions for Bankruptcy, Fictitious Bankruptcy or Causing to Become Bankrupt: Order of the Ministry of Economy of Ukraine No. 1361, October 26, 2010]. Retrieved from http://www.profiwins.com.ua/ uk/letters-and-orders/ministryof-economy/1343-1361.html (In Ukrainian).

24. Ministry of Finance of Ukraine. (2016). Pro zatverdzhennia Poriadku provedennia otsinky finansovoho stanu potentsiinoho benefitsiara investytsiinoho proektu, realizatsiia yakoho peredbachaietsia na umovakh finansovoi samookupnosti, a takozh vyznachennia vydu zabezpechennia dlia obsluhovuvannia ta pohashennia pozyky, nadanoi za rakhunok koshtiv mizhnarodnykh finansovykh orhanizatsii, obsluhovuvannia yakoi zdiisniuvatymetsia za rakhunok koshtiv benefitsiara: Nakaz Ministerstva finansiv 
Ukrainy № 616, 14.07.2016 [On approving the Procedure for assessing the financial condition of a potential beneficiary of an investment project, the realization of which is envisaged on the terms of financial selfsufficiency, as well as determining the type of security for servicing and repayment of the loan provided at the expense of international financial organizations, servicing of which will be carried out at the expense of the beneficiary: Order of the Ministry of Finance of Ukraine No. 616, July 14, 2016]. Retrieved from http:// zakon3.rada.gov.ua/laws/show/ z1095-16 (In Ukrainian).

25. Ministry of Finance of Ukraine. State Property Fund of Ukraine. (2001). Pro zatverdzhennia Polozhennia pro poriadok zdiisnennia analizu finansovoho stanu pidpryiemstv, shcho pidliahayut pryvatyzatsii: Nakaz № 49/121, 26.01.2001 [About shutting down the Provision on the order of health analysis of the financial camp of privatization, which privatization of privatization: Order No. 49/121, 01.26.2001]. Retrieved from http:// zakon3.rada.gov.ua/laws/show/ z0121-01 (In Ukrainian).

26. Mutovkina, N. Yu., \& Sergeev, M. Yu. (2019). Fuzzy evaluation of the technical re-equipment project efficiency. IOP Conference Series: Materials Science and Engineering. Cybernetics, Economics and Organization of Mechanical Engineering Production, 537. https://doi.org/10.1088/1757899X/537/4/042039
27. Ostapiuk, N., Karmaza, O., Kurylo, M., \& Timchenko, G. (2017). Economic security in investment projects management: convergence of accounting mechanisms. Investment Management and Financial Innovations, 14(3), 353360. http://dx.doi.org/10.21511/ imfi.14(3-2).2017.06

28. Romanova, Y. V., \& Vedyaeva, Y. S. (2018). Systemic approach to evaluating the efficiency of innovation projects. Vestnik Saratovskogo gosudarstvennogo sotsialnoekonomicheskogo universiteta, 1(70), 65-67. (In Russian).

29. Rostova, O., Shirokova, S., \& Sokolitsyna, N. (2019). Management of project for automation of investment control at industrial enterprise. IOP Conference Series: Materials Science and Engineering. Cybernetics, Economics and Organization of Mechanical Engineering Production, 537. https://doi.org/10.1088/1757899X/497/1/012017

30. Sonta-Draczkowska, E., \& Mrozewski, M. (2019). Exploring the Role of Project Management in Product Development of New Technology-Based Firms. Project Management Journal, $X X(X), 1-18$. https://doi. org/10.1177/8756972819851939

31. State Tax Service of Ukraine. (1998). Shchodo Metodychnykh rekomendatsii po analizu finansovo-hospodarskoho stanu pidpryiemstv ta orhanizatsii: Lyst
Derzhavnoi podatkovoi administratsii Ukrainy № 795/10/20-2117 vid 27.01.98 [Regarding the Methodological Recommendations for the Analysis of the Financial and Economic Condition of Enterprises and Organizations: Letter of the State Tax Service of Ukraine No. 795/10/20-2117 dated 27.01.98]. Retrieved from http://search. ligazakon.ua/1_doc2.nsf/link1/ GDPI1722.htm (In Ukrainian).

32. Strochilina, V. S. (2015). Tekhnologiya upravleniya po rezultatam v sisteme HRmenedzhmenta organizatsii [Result-based management technology in the organization's HR management system]. Ekonomika, upravlinnya, finansy: materialy IV Mizhnar. nauk. konf. (H. Perm, kviten 2015) (pp. 146149). (In Russian).

33. Sultanov, I. A. (2019). Plan deystviy pri upravlenii riskami proekta [Action plan for managing project risks]. Retrieved from http://projectimo.ru/upravlenie-riskami/ riski-proekta.html (In Russian).

34. Ukrainian Stock Market Infrastructure Development Agency. (2018). Retrieved from http:// smida.gov.ua (In Ukrainian).

35. Vitlinsky, V. V., \& Velikoivanenko, G. I. (2004). Ryzykolohiia v ekonomitsi ta pidpriiemnytstvi [Riskology in economics and entrepreneurship] (480 p.). Kyiv: KNEU. (In Ukrainian). 


\section{APPENDIX A}

Table A1. Ukrainian machine-building enterprises under study

\begin{tabular}{|c|c|}
\hline $\begin{array}{c}\text { Machine-building enterprises whose business operations } \\
\text { belong to the fourth technological paradigm }\end{array}$ & $\begin{array}{c}\text { Machine-building enterprises whose business operations } \\
\text { belong to the fifth technological paradigm }\end{array}$ \\
\hline $\begin{array}{l}\text { Korosten Chemical Engineering Plant; } \\
\text { Sumy Machine-Building Scientific Production Association; } \\
\text { Sumy Plant of Pumping and Power Engineering } \\
\text { "Nasosenergomash"; } \\
\text { Plant «Budmash»; } \\
\text { Kharkov Machine-Building Plant "LIGHT OF MINER"; } \\
\text { Novokramatorsky Machine-Building Plant; } \\
\text { Drohobych Machine-Building Plant; Borex; } \\
\text { Kyiv Motorcycle Plant; } \\
\text { Glukhiv Plant "Electropanel"; } \\
\text { Kharkiv Electrotechnical Plant "Ukrelectromash"; } \\
\text { Bolshevik Research and Production Enterprise }\end{array}$ & $\begin{array}{l}\text { Meridian. n. SP Korolev; } \\
\text { Motor Sich; } \\
\text { ELMIZ; } \\
\text { Artem; } \\
\text { Kyiv Radar Plan; } \\
\text { ELECTRONPRILAD; } \\
\text { Ivano-Frankivsk Plant "Promprylad"; Quasar; } \\
\text { Glukhiv Plant "Electropanel"; } \\
\text { Kharkiv Electrotechnical Plant "Ukrelectromash"; } \\
\text { Bolshevik Research and Production Enterprise }\end{array}$ \\
\hline
\end{tabular}

Note: The distribution is made based on Classification of Economic Activities (2011-2019). 